J. Clin. Chem. Clin. Biochem.

Vol. 21, 1983, pp. 577-582

\title{
An Evaluation of Immunoglobulin Assays on the ACA III
}

\author{
By T. Rammeloo and M. H. Beunis
}

Department of Clinical Chemistry, Stichting Samenwerking Delftse Ziekenhuizen, Delft, The Netherlands

(Received November 11, 1982/March 3, 1983)

Summary: We evaluated an immunoturbidimetric Du Pont ACA method for the determination of $\operatorname{IgG}, \operatorname{IgA}$ and IgM in serum. Between-day reproducibilities of the ACA assays were comparable to those of a radial immunodiffusion, a Hyland nephelometric and a turbidimetric assay on Centrifichem 400 . Correlations between results obtained by these methods were acceptable, but the results differed quantitatively. After simulated recalibration based on results of control sera or patient samples, the results for $\operatorname{IgA}$ and IgM became more interchangeable. IgM concentrations below $0.25 \mathrm{~g} / \mathrm{l}$, which are important for the assessment of intrauterine infections, could not be quantified with the ACA. Moderate levels of haemoglobin, bilirubin or lipids do not interfere with the ACA assays. The evaluated assays are fast and easy to use.

\section{Prüfung von Immunoglobulin-Bestimmungen mit dem ACA III}

Zusammenfassung: Eine immunturbidimetrische Methode für die Bestimmung von IgG, IgA und IgM im Serum mit dem DuPont ACA wurde geprüft.

Die Reproduzierbarkeit der Bestimmungen mit dem ACA von Tag zu Tag war vergleichbar mit der für die radiale Immundiffusion, Nephelometrie (Hyland) und Turbidimetrie (Centrifichem 400). Die Korrelation der mit diesen Methoden erhaltenen Ergebnisse war annehmbar, die Ergebnisse unterschieden sich jedoch quantitativ. Nach simulierter Rekalibrierung anhand der Werte von Kontrollseren oder Patientenproben wurde für die Ergebnisse von IgA- und IgM-Bestimmungen eine bessere Übereinstimmung erzielt. IgM-Konzentrationen unter $0,25 \mathrm{~g} / \mathrm{l}$, wichtig für die Feststellung intrauteriner Infektionen, konnten mit dem ACA nicht bestimmt werden. Hämoglobin, Bilirubin oder Lipide stören - soweit untersucht - die Bestimmungen mit dem ACA nicht. Die geprüften Methoden sind schnell und einfach im Gebrauch.

\section{Introduction}

Several techniques such as radial immunodiffusion turbidimetry $(1,2)$ and nephelometry $(3,4)$ can be used for the assessment of immunoglobulin concentrations.

Radial immunodiffusion requires an incubation time of at least two days. Most nephelometric immunoassays and turbidimetric immunoassays are rather expensive, because a standard curve is needed with each run.

Recently, Du Pont introduced an ACA-assay for the assessment of immunoglobulins in serum. ACA-assays, like most nephelometric and turbidimetric as- says, are based on the reactions of antigens with specific antibodies in a polyethylene glycol 6000 solution. The light-scattering of the immunecomplexes is measured turbidimetrically as the difference in absorbance at 340 and $540 \mathrm{~nm}$. In contrast to the methods mentioned above, the ACA-assay is advantageous in obtaining the result from a single sample within a few minutes. We therefore evaluated the ACA-assay and compared its reproducibility and accuracy with those of commonly used assays. Special attention was given to the determination of low $\operatorname{IgA}$ and IgM concentrations, because the diagnosis of selective $\operatorname{IgA}$ deficiency or a previous intra-uterine infection by newborns requires low detcction limits of

J. Clin. Chem. Clin. Biochem. / Vol. 21, 1983 / No. 9 
$\lg \mathrm{A}$ and $\lg \mathrm{M}$. Furthermore, we tested haemoglobin, bilirubin and lipids for possible interference in the ACA-assays.

We expected that different immunoglobulin concentrations would be given by the four assays $(5,6,7)$. It would be desirable, however, to obtain directly comparable results when shifting from any of the routine methods to the ACA method. We therefore simulated a recalibration of the ACA, based on values from control sera and from patient samples.

\section{Materials and Methods}

Methods

The ACA assays were performed on an ACA III instrument (E.I. Du Pont de Nemours \& Co., Inc., Wilmington. U.S.A.).

Radial immunodiffusion (RID) was performed with Partigen plates and standards from Behringwerke (Marburg, F.R.G.) according to the supplier's instructions.

The nephelometric immunoassay (NIA) was performed on a $\mathrm{Hy}$ land PDQ nephelometer, automated with the disc 120 (Hyland Division, Travenol Laboratories, Costa Mesa, U.S.A.) according to the instructions of the manufacturer. Hyland reference serum A (lot no OA 03A001) was used as a standard serum.

The turbidimetric immunoassay (TIA) was performed on a Centrifichem 400, as described by Boigne et al. (2) with some modifications. We used antisera and buffered polyethylene glycol solution from Orion (Orion Diagnostika, Helsinki, Finland). The standard serum used was the same as that applied in the nephelometric assay.

\section{Patient samples}

Sera from patients were collected over a period of 4 months and immediately frozen at $-70^{\circ} \mathrm{C}$.

For the comparative study, haemolytic, icteric and lipaemic sera were excluded.

For interference studies, five specimens with varying degree of haemolysis were prepared from clotted blood samples. The highest haemoglobin level was $1.5 \mathrm{mmol} / \mathrm{l}$. Five icteric serum samples with increasing bilirubin concentrations up to $324 \mu \mathrm{mol} / /$ were taken from the laboratory workload. Five serum samples with visible lipaemia were selected.

For the determination of low IgM concentrations 10 cord citrate plasmas were collected.

\section{Quality control samples}

Five control sera were used to determine the experimental variation of each immunoglobulin assay on the ACA: two selected patient sera (one containing a low, the other a high concentration); the ACA calibrator of middle-range concentration; a commercial control serum (Seronorm Protein, lot no 102, Nyegaard, Oslo, Norway) which was also used in the other methods; and reference serum $A$, the standard of the nephelometric assay.

\section{Statistical methods}

The within-day imprecisions of the five control sera were calculated from 20 duplicate results. The five within-day imprecisions, tested on homogeneity (Burlett's test) were pooled to obtain an estimated within-day standard deviation ( $\mathrm{df}=$ degrees of free$\operatorname{dom}=95)(17)$.
During 20 days the five control scra, mentioned before, were assayed each day in duplicate. The between-day standard deviation was cstimated from the duplicate results of 50 patient scra (duplicates obtained on different days), and from the results of the 5 control sera. The between-day standard deviation was tested against the within-day standard deviation (Fisher-test). The linear functional relationship of the ACA assay with each of the three other assays was calculated by the method of least squares, corrected for experimental errors in both methodds (8).

\section{Results}

The pooled within-day and between-day standard deviations of the ACA-assays for IgG, IgA and IgM are given in table 1 .

Tab. 1. Imprecision of the ACA immunoglobulin assays

\begin{tabular}{llll}
\hline Standard deviation & $\begin{array}{l}\text { IgG } \\
(\mathrm{g} / \mathrm{l})\end{array}$ & $\begin{array}{l}\text { IgA } \\
(\mathrm{g} / \mathrm{l})\end{array}$ & $\begin{array}{l}\text { IgM } \\
(\mathrm{g} / \mathrm{l})\end{array}$ \\
\hline Swithin-day $\left.^{*}\right)$ & 0.17 & 0.05 & 0.03 \\
serwecn-day $\left.^{* *}\right)$ & 0.40 & 0.10 & 0.06 \\
\hline
\end{tabular}

*) S Sithin-day was estimated from standard deviations of 20 duplicate determinations of calibrator 3. low and high serum pools, reference serum $A$ and Seronorm Protein $(\mathrm{df}=95)$.

**) Shetween-day was estimated from duplicate results of 50 human sera assayed independent on different days $(\mathrm{df}=50)$.

The between-day standard deviation for the three assays appeared to be significantly $(p<0.05)$ larger than the within-day standard deviation.

The between-day reproducibilities of the ACA and the three other methods, determined for the same control serum, are given in table 2. Table 2 shows that the reproducibilities for all methods were acceptable.

A low and a high polyclonal serum sample (IgG 1.57 and $24.6 \mathrm{~g} / 1$ respectively) were mixed in 4 known ratios. The expected concentrations were compared with the measured concentrations (average of 5 measurements). Linear $y x$-regression of the mea-

Tab. 2. Between day reproducibilities of 4 different methods for immunoglobulin assays applied to seronorm protein.

\begin{tabular}{lllll}
\hline \multicolumn{5}{c}{ Mean \pm standard deviation } \\
Method & $n$ & $\begin{array}{l}\mathrm{IgG} \\
(\mathrm{g} / \mathrm{l})\end{array}$ & $\begin{array}{l}\mathrm{IgA} \\
\mathrm{g} / \mathrm{l})\end{array}$ & $\begin{array}{l}\mathrm{IgM} \\
(\mathrm{g} / \mathrm{l})\end{array}$ \\
\hline Aca & 20 & $11.1 \pm 0.5$ & $2.34 \pm 0.13$ & $1.25 \pm 0.08$ \\
RID & 20 & $12.5 \pm 0.3$ & $2.28 \pm 0.06$ & $1.18 \pm 0.07$ \\
$\begin{array}{l}\text { NIA } \\
\text { (Hyland) }\end{array}$ & 20 & $11.7 \pm 0.8$ & $2.18 \pm 0.10$ & $1.28 \pm 0.11$ \\
$\begin{array}{l}\text { TIA } \\
\text { (Centrifichem) }\end{array}$ & 20 & $11.6 \pm 0.4$ & $2.16 \pm 0.04$ & $1.24 \pm 0.05$ \\
\hline
\end{tabular}

J. Clin. Chem. Clin. Biochem. / Vol. 21, 1983 / No 9 
sured on the expected concentrations gave a slope of 0.99 (s.d. 0.01 ) and an $y$-intercept of 0.05 (s.d. $0.09) \mathrm{g} / \mathrm{l}$.

ACA-assays were compared with radial immunodiffusion, turbidimetric and nephelometric assays by analysing 50 human scra in duplicate (on different days). The ACA results were plotted against the results of the other methods (fig. 1).
In addition, the results from 10 sera with low $\operatorname{Ig} A$ concentrations $(0.1$ to $0.8 \mathrm{~g} / \mathrm{l})$ were compared. The functional relationships were comparable to those shown in fig. 1:

$$
\begin{aligned}
& y(A C A)=0.13+1.09 \times(\text { RID }), \\
& y(A C A)=0.05+1.14 \times(\text { NIA }) \text { and } \\
& y(A C A)=0.03+1.17 \times(\text { TIA })
\end{aligned}
$$
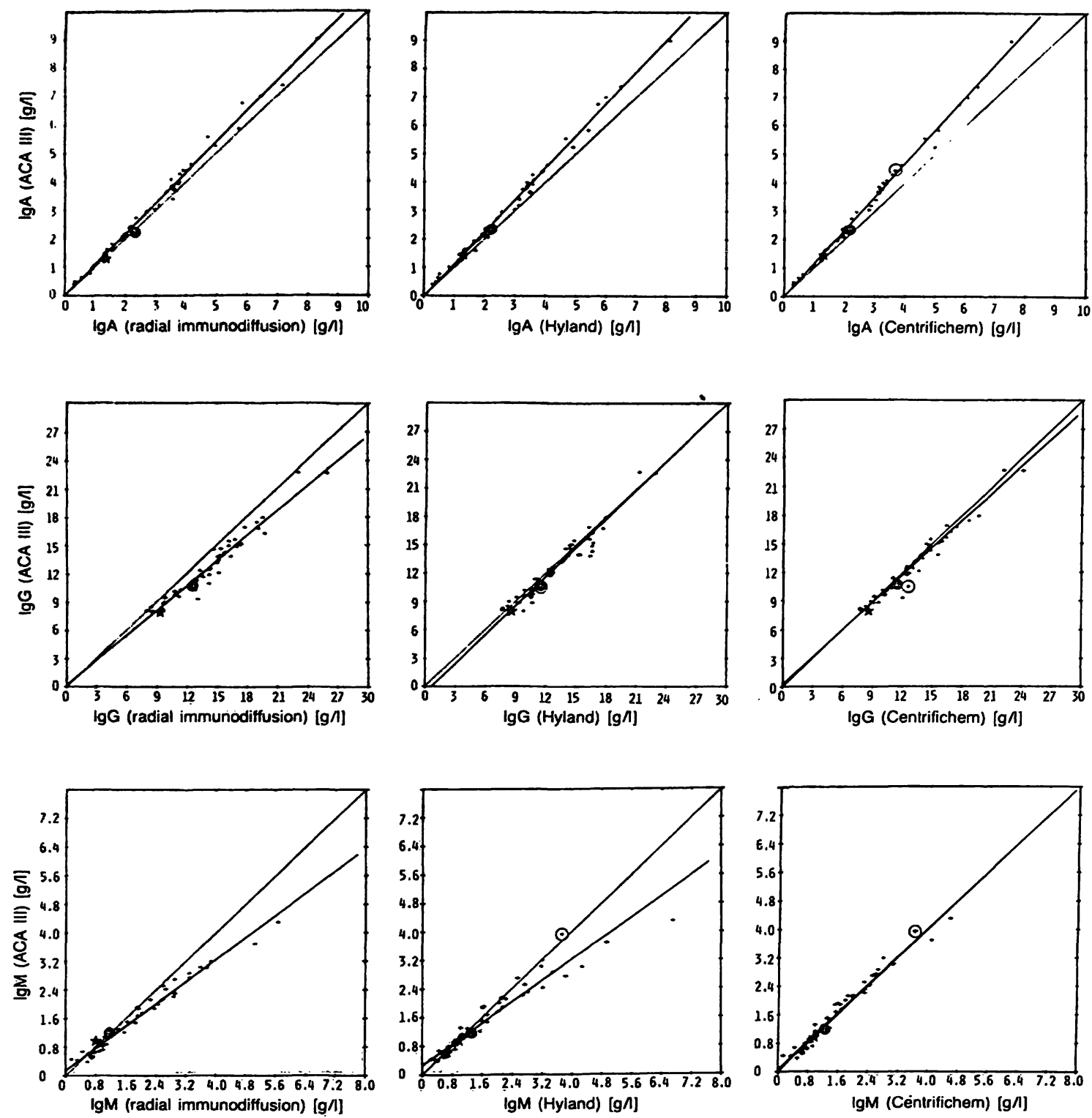

- Fig. 1. Graphic representations of functional relationships between serum immunoglobulin assay results as found with ACA III (y) and radial immunodiffusion, nephelometry (Hyland) and turbidimetry (Centrifichem) (x).

IgA $(n=50)$ : radial immunodiffusion $y=-0.001+1.08 x ; s_{y x}=0.18$

Hyland $y=-0.03+1.13 x ; s_{y x}=0.17$

Centrifichem $y=-0.16+1.17 x ; s_{y x}=0.15$

$\lg (\mathrm{n}=50)$ : radial immunodiffusion $\mathrm{y}=0.17+0.88 \mathrm{x} ; \mathrm{s}_{\mathrm{yx}}=0.80$

Hyland $y=-0.67+1.02 x ; s_{y x}=0.80$

Centrifichem $y=0.26+0.95 x ; s_{y x}=0.64$

$\operatorname{IgM}(n=49)$ : radial immunodiffusion $y=0.15+0.78 x ; s_{y x}=0.16$

Hyland $y=0.26+0.74 x ; s_{y x}=0.26$

Centrifichem $y=0.06+0.99 x ; s_{y x}=0.17$

- Mean of 20 results for Seronorm Protein with both methods.

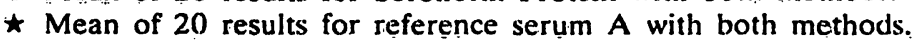

$\oplus$ Mean of 20 results for ACA calibrator 3; mean of 2 results with Hyland or Centrifichem. 
To determine IgM concentrations at the lower limit of the measurement range of the ACA method $(0.25$ $\mathrm{g} / \mathrm{l})$ and below, we increased the sensitivity by applying a 5 -fold predilution instead of the usual 20 -fold dilution; the resulting IgM values showed a distinct positive bias of about $0.1 \mathrm{~g} / \mathrm{l}$.

To test for interference by bilirubin, haemoglobin or lipids, immunoglobulins were determined in 5 haemolytic, 5 icteric and 5 lipaemic sera. No significant interference was found for $\operatorname{IgG}$. The $\operatorname{IgA}$ assay on the ACA was influenced only by large amounts of haemoglobin; haemoglobin of about $1.5 \mathrm{mmol} / \mathrm{l}$ caused a positive interference equivalent to approximately $3 \mathrm{~g} / \mathrm{l}$ of $\operatorname{IgA}$. The IgM assay on the ACA tended to show a positive interference by bilirubin and lipids, whereas haemoglobin of about 0.5 $\mathrm{mmol} / \mathrm{l}$ apparently increased the IgM concentration by $1 \mathrm{~g} / 1$ (fig. 2).

Although the correlations between the methods were acceptable, the results showed quantitative differences, which preclude the possibility of transferring from one method to an other. Attempting to solve this problem, we simulated recalibration of the ACA. Reference serum used as a standard in the nephelometric and turbidimetric assays was also assessed by the ACA and radial immunodiffusion. Taking this reference serum as a general standard, we multiplied the results of the ACA by the ratio of the reference and ACA value. Thereafter we recalculated the functional relationships (tab. 3).

In the same way we simulated a recalibration of the ACA based on a control serum. The recalculated relationships are also shown in table 3.

Since the simulated recalibrations did not solve the whole problem, especially not for IgM, we also recal-

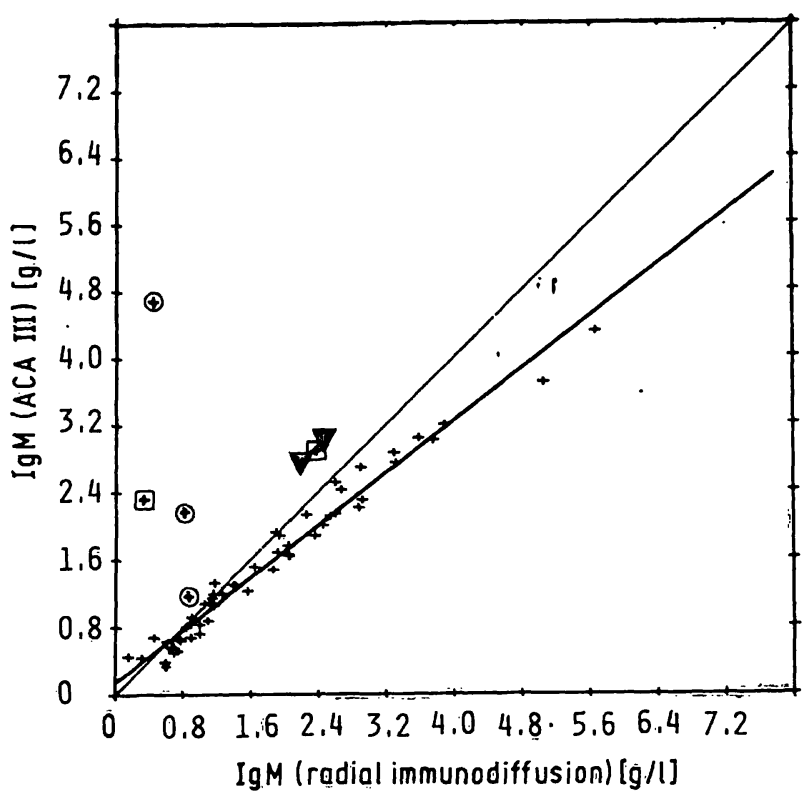

Fig. 2. Interference by haemoglobin, bilirubin and lipids in the ACA III immunoglobulin $M$ assay.

$\oplus$ Results of 3 samples with haemoglobin concentrations of about $0.2,0.5$ and $1.5 \mathrm{mmol} / /$ causing increasing interference.

A Results of 2 samples with total bilirubin concentrations of 225 and $324 \mu \mathrm{mol} / \mathrm{l}$.

$\boxplus$ Results of 2 samples with gross lipaemia.

+ Results of non-haemolytic, non-icteric or non-lipaemic serum samples.

ibrated the ACA using the results obtained with patient samples: we divided 50 samples into equal groups, then calculated the functional relationships between the ACA and the other methods for the results obtained with the samples of the first group. We corrected the ACA results of the samples in the second group for the calculated slope of the functional relationship. Thereafter we recalculated the func= tional relationships for the samples of the second group (tab. 3).

Tab. 3. The effect of the ACA calibration on the calculated functional relationships. In calculating the functional relationships, the values obtained with radial immunodiffusion, nephelometric (Hyland) or turbidimetric assay (Centrifichem) were kept constant, and the $y$-values obtained with the ACA assays were corrected by a factor derived from the results of reference serum, control serum or patient samples.

\begin{tabular}{|c|c|c|c|c|}
\hline $\begin{array}{l}\text { Method } \\
x\end{array}$ & ACA-calibrators & $\begin{array}{l}\text { Reference serum } \\
\text { (Hyland) }\end{array}$ & $\begin{array}{l}\text { Control serum } \\
\text { Seronorm Protein }\end{array}$ & $\begin{array}{l}\text { Patient } \\
\text { samples }\end{array}$ \\
\hline \multicolumn{5}{|l|}{$\lg G$} \\
\hline RID & $0.17+0.88 x$ & $0.05+1.05 x$ & $0.05+1.04 x$ & $-0.39+1.06 x$ \\
\hline NIA & $-0.67+1.02 x$ & $-0.60+1.10 x$ & $-0.57+1.07 x$ & $-1.44+1.11 x$ \\
\hline TIA & $0.26+0.95 x$ & $0.81+1.01 x$ & $0.78+1.01 x$ & $-0.44+1.10 x$ \\
\hline \multicolumn{5}{|l|}{$\operatorname{Ig} A$} \\
\hline RID & $-0.001+1.08 x$ & $-0.02+1.02 x$ & $-0.02+1.05 x$ & $=0.03+1.04 x$ \\
\hline NIA & $-0.03+1.13 x$ & $-0.03+1.04 x$ & $-0.03+1.06 x$ & $-0.02+1.02 x$ \\
\hline TIA & $-0.16+1.17 x$ & $-0.02+1.08 x$ & $-0.02+1.08 x$ & $-0.02+1.02 x$ \\
\hline \multicolumn{5}{|r|}{$-0.0<+1.0<x$} \\
\hline RID & $0.15+0.78 x$ & $0.16+0.67 x$ & $0.17+0.79 x$ & $0.36+1.03 x$ \\
\hline NIA & $0.26+0.74 x$ & $0.31+0.73 x$ & $0.34+0.80 x$ & $0.03+1.00 x$ \\
\hline TIA & $0.06+0.99 x$ & $0.06+1.01 x$ & $0.09+1.06 x$ & $0.26+1.05 x$ \\
\hline
\end{tabular}




\section{Discussion}

The reproducibility of the ACA was comparable to those of the other methods (tab. 2). The experimental error of a single measurement was almost entirely determined by the between-day variation of the instrument. Variation due to predilution errors appeared to be relatively small.

Similarity between the ACA calibrators and human serum, tested in the IgG-assay, was quite satisfactory. We did not test the similarity between the calibrators and monoclonal immunoglobulins, since it can be anticipated from results obtained with the other methods that some of those would behave similarly and some would not $(9,10,11)$.

The range of the ACA assay, from the lowest to the highest calibrator, was sufficient to meet general clinical requirements: for IgG from 1.0 to $60 \mathrm{~g} / \mathrm{l}$ and for IgA and IgM from 0.25 to $15 \mathrm{~g} /$ l. In exceptional cases, a reliable determination of low IgA or IgM levels is clinically obligatory. In the low IgA range $(0.1$ to $0.8 \mathrm{~g} / \mathrm{l})$ the same relationships between the ACA and the other methods are found, but none of the methods tested would be sensitive enough to detect IgA-deficiency. The same holds for the determination of immunoglobulin concentrations in cerebrospinal fluid. In such cases more sensitive methods, i.e. radioimmunoassay or haemagglutination should be applied (12). The upper reference limit of the IgM concentration in serum of newborns is about $0.20 \mathrm{~g} / \mathrm{l}$. An IgM concentration above this limit can be an indication of intra=uterine infection. Because the lower limit of the ACA method is $0.25 \mathrm{~g} / \mathrm{l}$, we increased the sensitivity of the IgM assay by applying a 5-fold predilution. This approach cannot be recommended, however, because it resulted in a positive bias of $0.1 \mathrm{~g} / \mathrm{l}$.

Interference by haemoglobin, bilirubin or lipids in the ACA assays was related to the sample size required: $320 \mu \mathrm{l}$ for $\operatorname{IgM}, 100 \mu \mathrm{l}$ for $\operatorname{IgA}$ and $80 \mu \mathrm{l}$ for IgG. This effect might be explained from the bichromatic measurement on the ACA. The turbidity was measured as the difference in absorbances at 340 and $540 \mathrm{~nm}$. As a haemoglobin concentration of 0.5 $\mathrm{mmol} / \mathrm{l}$ also causes a different absorbance at these two wavelengths, apparently higher IgM results were obtained (fig. 2). Therefore we recommend that visibly lipaemic, icteric or haemolytic samples should be excluded from determination of immunoglobulins, especially IgM on the ACA.

Although the correlations between the results of the different method's compared were acceptable, quantitative differences in immunoglobulin concentra- tions were found. These differences are easily ascribed to the standards used (13). To test this assumption, we simulated recalibrations of the ACA on a general standard and a commonly used control serum. From table 3 it is obvious that the recalculated functional relationships were improved for $\operatorname{IgG}$ and IgA, but not for IgM. Thus the differences in the IgM results cannot be ascribed to the standards alone. Other possible causes, mentioned in the literature, are the use of different antisera, diluents containing various amounts of polyethylene glycol (14) or simply the different measuring principles of the methods $(15,16)$.

The reaction conditions, which can influence the results, are inherent to the method applied in the individual laboratory. If a laboratory used several methods, it might not be sufficient to use the same standard and antiserum. By doing this in the present study, we did not obtain the same results for IgM by the turbidimetric assay (Centrifichem) and the nephelometric assay (Hyland). Therefore, we strongly recommend calibration of the ACA (or any other method) with patient samples. Although functional relationships of $\operatorname{IgA}$ and $\operatorname{IgG} \operatorname{did}$ not improve very much or even became worse (almost certainly due to statistical variation of the results), IgM results obtained in this way became interchangeable.

After calibration, the ACA assays of immunoglobulins are easy to perform over a wide clinical range, except for low IgA and IgM concentrations. We recommend, however, that a filter balance be performed before determining the immunoglobulin concentrations on the ACA, because the immunoglobulin assay on the ACA appeared to be more sensitive to errors in the filter range of the instrument than any of the other assays on the ACA.

The ACA assays present a good alternative for the assessment of the immunoglobulins in laboratories with a relatively small work load, and for emergency determinations.

\section{Acknowledgements}

We thank Mr. J. Jongeneel (Holy Ziekenhuis. Vlaardingen, The Netherlands), Mr. J.A.P. Stroes, Ph. D and staff (Stichting Samenwerking Delftse Ziekenhuizen, Delft, The Netherlands) for their co-operation, Bernic Ceulen, Trudy' van Leeuwen, Magda van Wissen and Chris van Poclje for their technical assistance. Herman Buis and Mr. K. Stinshoff, Ph. D. (Du Pont) are acknowledged for supplying us with reagents and financial support. 


\section{References}

1. Blom, M. \& Hjorne, N. (1976) Clin. Chem. 22, 657-662.

2. Boigne. J. M.. Boigne, N., Galacteros, F., Nalpas, B. \& Philippon, C. (1977) Ann. Biol. Clin. 35, 237-254.

3. Whicher, J. T., Perry, D. E. \& Hobbs, J. R. (1978) Ann. Clin. Biochem. 15, 77-85.

4. Whicher, J. T. \& Blow, C. (1980) Ann. Clin. Biochem. 17. 170-177.

5. Shulman. G. (1980) Ann. Clin. Biochem. 17, 178-182.

6. Dito. W. R.. Tucker, E. S. \& Nakamura. R. M. (1981) Am. J. Clin. Pathol. 76. 753-759.

7. Landaas. S., Skrede, S. \& Eldjarn. L. (1978) Scand. J. Clin. Lah. Invest. 38. 295-299.

8. Deming. W. E. (1943) Statistical adjustment of data. John Wiley and Sons. New York, NJ.

9. Virella. G. \& Fudenberg, H. H. (1977) Clin. Chem. 23, 1925-1928.

10. Cloppet. H.. Francina, A., Coquelin. H.. Boucaud-Maitre, Y.. Hutinel. P. \& Creyssel, R. (1982) Clin. Chem. 28. 180182.
11. Whicher, J. T. (1980) La Ricerca Clin. Lab. 10, 189-195.

12. Dionne, J. A. \& Peoples, J. C. A. (1978) In Automated Immunoạnalysis, part 1, (R. F. Ritchie, ed.) pp. 227-237, Marcel Dekker, New York.

13. Milford Ward, A. (1980) La Ricerca Clin. Lab. 1.0, 213-217.

14. Pesce, M. A. \& Bodourian, S. H. (1982) Clin. Chem. 28, 516-5.19.

15. Whicher, J. T., Hunt, J., Perry, D. E., Hobbs, J. E., Fifield, R., Keyser, J., Kohn, J., Riches, P., Smith, A. M.. Thompson, R. A., Milforward, A. \& White, P. (1978) Clin. Chem. 24, 531-535.

16. De Bruyn. A. M., Klein, F., Neumañn, H., Sandkuyl, L. A.. Vermeeren, R. \& Le Blansch, G. (1982) J. Immunol. Methods $48,339-348$.

17. Dixon, W. J. \& Massey, F. J. (1969) Introduction to statistical analysis, 3rd ed, McGraw-Hill. London. pp. 112-113.

Ir. T. Rammeloo Stichting Samenwerking

Delftse Ziekenhuizen

Klinisch Chemisch Laboratorium

Postbus 5010

NL-2600 GA Delft 